\title{
Chair of Wi-Fi safety panel steps down
}

$\mathrm{F}$ acing public controversy over a potential conflict of interest revealed in a CMAJ investigation, the chair of a Royal Society of Canada panel reviewing federal safety guidelines for $\mathrm{Wi}-\mathrm{Fi}$, cellphones and other radiofrequency devices has stepped aside.

Daniel Krewski, a professor in the faculty of medicine at the University of Ottawa in Ontario, failed to disclose a $\$ 126000$ contract in 2008-2009 from Industry Canada to "assist in addressing what the Department believes is opposition often based on misperception and misinformation" with respect to cellphone antennas. Krewski did, however, disclose that he had performed extensive government contract work.

After learning of Dr. Krewski's omission, Geoffrey Flynn, who chairs the Royal Society's Committee on Expert Panels and its Scientific Advisory Committee, told $C M A J$ he would "take it back to the panels." Krewski did not respond to an interview request following his departure. Flynn also declined an interview request.

In a statement on its website, the Royal Society says it has "undertaken to identify a new Chair of the Expert Panel."

The Royal Society also posted a statement explaining that "in order to avoid further occurrences of this type, the Royal Society will not comment further on the work of the Expert Panel on Safety Code 6 until the panel's final report has been completed, peer-reviewed, and submitted to Health Canada, the sponsor of this report." This statement was subsequently removed from the society's website.

Shortly before announcing Krewski's resignation, the Royal Society postponed a public meeting on the safety review that was scheduled for July 8 in Ottawa. "A large outpouring of interest in this event," the society explained, made it "challenging to organize in the current circumstances. We are therefore rescheduling the consultation for later this summer."



The Royal Society of Canada is looking for a new chair to lead an expert panel assessing safety guidelines for Wi-Fi and wireless devices.

Magda Havas, an associate professor of environmental and resource studies at Trent University in Peterborough, Ontario, welcomed the news of Krewski's resignation.

"Dr. Krewski, as well as several other members of the expert panel, have had industry contracts for a very long time and are known, within the scientific community, to support the outdated and ineffective guidelines," she explained. "I have not witnessed such blatant disregard for an independent scientific review in my entire professional career."
Frank Clegg, spokesperson for Canadians for Safe Technology - a group based in Oakville, Ont., that wants tougher federal safety rules on radiofrequency devices - also says he welcomes the news of Krewski's resignation. But serious concerns remain about possible conflicts of interest among the remaining seven panelists, he says. "We believe three other remaining members of the panel are severely conflicted." Paul Webster, Toronto, Ont.

CMAJ 2013. DOI:10.1503/cmaj.109-4549 